\title{
Sedimentary Carbon Oxidation and Denitrification on the Shelf Break of the Alaskan Beaufort and Chukchi Seas
}

\author{
John P. Christensen* \\ Bigelow Laboratory for Ocean Sciences, 180 McKown Point, W. Boothbay Harbor, Maine 04575, USA
}

\begin{abstract}
Sediment-water fluxes were measured on transects across the northern Alaskan continental margin. Dissolved oxygen fluxes approximated total carbon dioxide fluxes when fluxes were low, but oxygen underestimated the higher total carbon dioxide fluxes. This follows a diagenetic model in which aerobic sediments occur below $86 \mu$ mol total carbon dioxide $\mathrm{m}^{-2} \mathrm{~h}^{-1}$ and anaerobic conditions intensify with increased organic matter loading. The relationship between the fluxes of nitrogen gas and total carbon dioxide agreed with the Redfield ratio, indicating that regenerated nitrogen predominantly returned to the overlying waters as nitrogen gas. On each transect, highest fluxes were found in a $20 \mathrm{~km}$ wide band located seaward of the $100 \mathrm{~m}$ continental shelf break. The magnitude of fluxes in these richer sediments exceeded that expected from the low productivity found on the outer continental shelf, suggesting upwelling-induced higher productivity at the shelf break.
\end{abstract}

\section{INTRODUCTION}

Ecosystems on continental shelves generally are highly productive relative to most open ocean regions, perhaps accounting for $20-38 \%$ of the global marine primary productivity and a large fraction of the global new production [1-4]. Within these ecosystems, benthic communities play an important role by receiving and oxidizing substantial fractions of the productivity $[5,6]$. The most common measure of this benthic role is the oxygen flux into the sediments $[7,8]$. Yet, oxygen fluxes from several dramatically different continental shelves were well fit by a single power curve regression solely against water-column depth [9], suggesting that oxygen fluxes are limited by factors other than just organic matter supply to the benthos. Oxygen fluxes do not account for anaerobic processes, such as sulfate reduction and denitrification, which occur deeper in the sediment column, and these respiration types show dramatic variation with water column depth and between different continental shelves $[5,9]$. The impact of anaerobic processes is that the overall stoichiometries of oxygen, carbon, and nitrogen, as measured at the top of the sediment column in flux incubation experiments, should vary dramatically from the Redfield ratios for aerobic water-column remineralization [10]. One particularly important process, denitrification, removes regenerated inorganic nitrogen by conversion to nitrogen gas $\left(\mathrm{N}_{2}\right)[11,12]$. Denitrification may match or exceed the fluxes of ammonium or nitrate leaving the sediments $[13,14]$. As a consequence, denitrification acts to reduce the role of nitrogen recycling within an ecosystem and thereby lessen its overall productivity.

The Chukchi Sea is a wide $(800 \mathrm{~km})$ shallow continental shelf with high productivity at its southern end near the

*Address correspondence to this auhor at the Bigelow Laboratory for Ocean Sciences, 180 McKown Point, W. Boothbay Harbor, Maine 04575, USA; E-mail: jchristensen@ bigelow.org
Bering Strait [15-17] and with a rich benthic community $[18,19]$. The long transit time of waters from the Bering Strait to the deep Arctic basins [20-21] implies significant nutrient recycling as the waters move northward. High denitrification rates found in Chukchi sediments [14] suggest a continual and significant loss of nitrogen from the overlying waters in this northward drift and a much lower productivity on the northern shelf break, where productivities of $50 \mathrm{~g}-\mathrm{C}$ $\mathrm{m}^{-2} \mathrm{y}^{-1}$ have been found [16,17,22]. Since the Canada Basin north of the Chukchi Sea drops quickly to depths greater than $3000 \mathrm{~m}$, significant differences in sediment respiration rates and their relationships should occur across the shelfslope region.

In this study, carbon oxidation and denitrification in shelf and slope sediments of the Chukchi and Beaufort Seas north of Alaska were investigated by collecting sediment cores and incubating them for measurement of sediment-water fluxes of total carbon dioxide $\left(\mathrm{TCO}_{2}\right)$, oxygen, nitrogen gas, and inorganic nutrients. This report describes the stoichiometries, magnitudes, and distribution of these fluxes in summer, 2004.

\section{MATERIALS AND METHODS}

Sediment cores were collected using a General Oceanics multiple corer from the shelf and slope region north of Alaska in July-August, 2004 (Fig. 1, Table 1). A vertical subcore was taken from each multiple corer core. The subcore, an acrylic tube with an inner area of $53.52 \mathrm{~cm}^{2}$ containing 3-10 cm of clear overlying water and $20 \mathrm{~cm}$ of sediment, was stoppered at both ends, and the top stopper had an attached teflon stirring bar and two sampling ports of $3.2 \mathrm{~mm}$ nylon tubing with on-off values for input of fresh bottom waters and output of overlying water samples. Subcores were maintained in a darkened walk-in refrigerator at $0.4^{\circ} \mathrm{C}$.

For each subcore, a reservoir of freshly-collected bottom water was maintained in the refrigerator open to the air and 


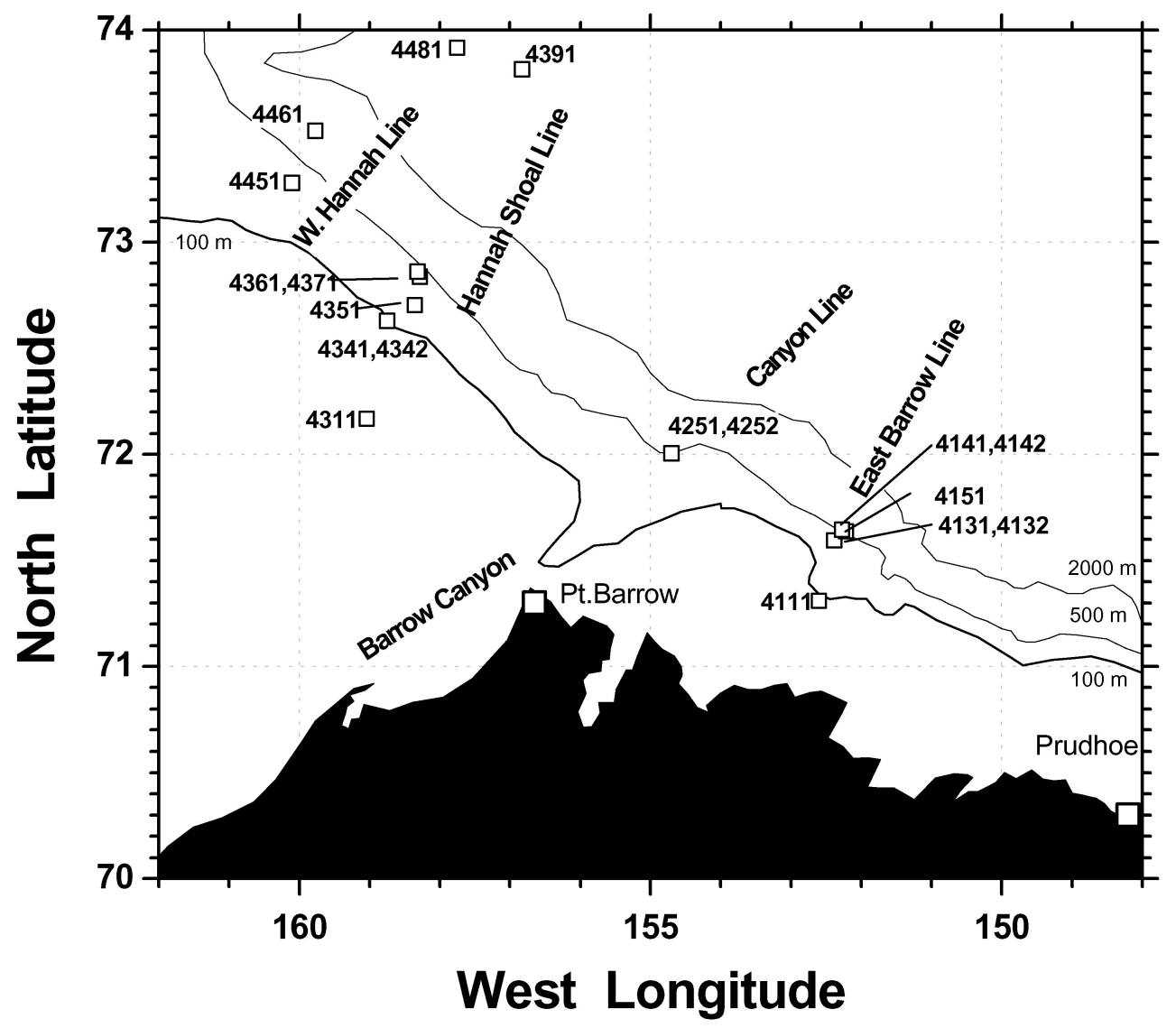

Fig. (1). Map of the sampling locations on the continental shelf and slope of the Chukchi and Beaufort Seas. The names of the four transect lines are shown. Numbers beside the symbols are the core number for each location.

connected to the inlet port of the flux core. The initial overlying water in each core was flushed without introduction of bubbles by opening both the inlet and outlet values and allowing reservoir water to flow via gravity through the enclosed core until at least twice the total volume of overlying water within the core had been replaced. Flux measurements began by closing both values and starting the stirrer. Over the next several days, samples were collected for inorganic salts (total carbon dioxide and nutrients) and for gases (total gas content, ${ }^{16} \mathrm{O}_{2},{ }^{14} \mathrm{~N}_{2}$, and argon). At each core sampling, stirring was stopped and the inlet and outlet ports of the core were opened, allowing reservoir water to accumulate at the top of the overlying water and pushing mid level water through the outlet port for collection. A sample of the reservoir was also drawn. Total carbon dioxide samples were stored in the refrigerator until measured using a gas chromatograph (see below). Nutrient subsamples were filtered through $0.4 \mu \mathrm{m} 25 \mathrm{~mm}$ Nucleopore polycarbonate filters. Silicate subsamples of the nutrient samples were refrigerated until measurement via the method in [23]. The other nutrients were stored frozen and are not reported here. Gas samples, taken with a 6-port gas-tight Valco valve with a $4.40 \mathrm{ml}$ sample loop, were immediately run via a coupled gas chromatograph and mass spectrometer.

Total carbon dioxide was determined by high precision gas chromatography using a Shimadzu GC8A chromatograph. A sample was isolated in a gas-tight Teflon Rheodyne valve with a $1.113 \mathrm{ml}$ sample loop. The sample valve was mounted in the helium flow-path to the water stripper. After rinsing the flow-path with $30 \%$ phosphoric acid and flushing the flow-path with helium for one minute, the sample was injected into the flow-path. The helium $(200 \mathrm{cc} / \mathrm{min}$.) pushed the sample into the $4 \mathrm{ml}$ stripper containing $1.0 \mathrm{ml}$ of $30 \%$ phosphoric acid. Immediately after the sample was injected, $0.5 \mathrm{ml}$ of $30 \%$ phosphoric acid was injected by a second gastight Teflon sample valve. This valve preceded the seawater sample valve so this acid rinsed the seawater sample loop and acidified any residual seawater in the seawater valve. Under acid conditions within the stripper, the carbon dioxide of the seawater sample was stripped from the liquid phase, passed through a Permapure water trap to remove water vapor and then was quantitatively trapped on Poropak $\mathrm{N}$ maintained at $-80^{\circ} \mathrm{C}$. Four minutes after sample injection, the Poropak $\mathrm{N}$ trap was switched to the analytical flow-path with helium carrier gas at $20 \mathrm{cc} / \mathrm{min}$. flow, and the trap was heated to $150^{\circ} \mathrm{C}$. The carbon dioxide passed through a separation column (183 cm length $\mathrm{x} 3.2 \mathrm{~mm}$ diameter) of Poropak $\mathrm{N}$ and $\mathrm{Q}\left(50 \%\right.$ each) at $150^{\circ} \mathrm{C}$. The quantity of carbon dioxide was measured in a hot wire detector against a reference helium flow of $20 \mathrm{cc} / \mathrm{min}$. Standards were prepared from analytical sodium carbonate in deionized water. Precision of the standards (standard error of the mean) averaged $0.2 \%$ of the mean value. This procedure was found to give a linear response with identical precision over the range of 0 10 mmole $\mathrm{TCO}_{2} / \mathrm{L}$. 
Table 1. Locations and Sampling Dates for Flux Cores

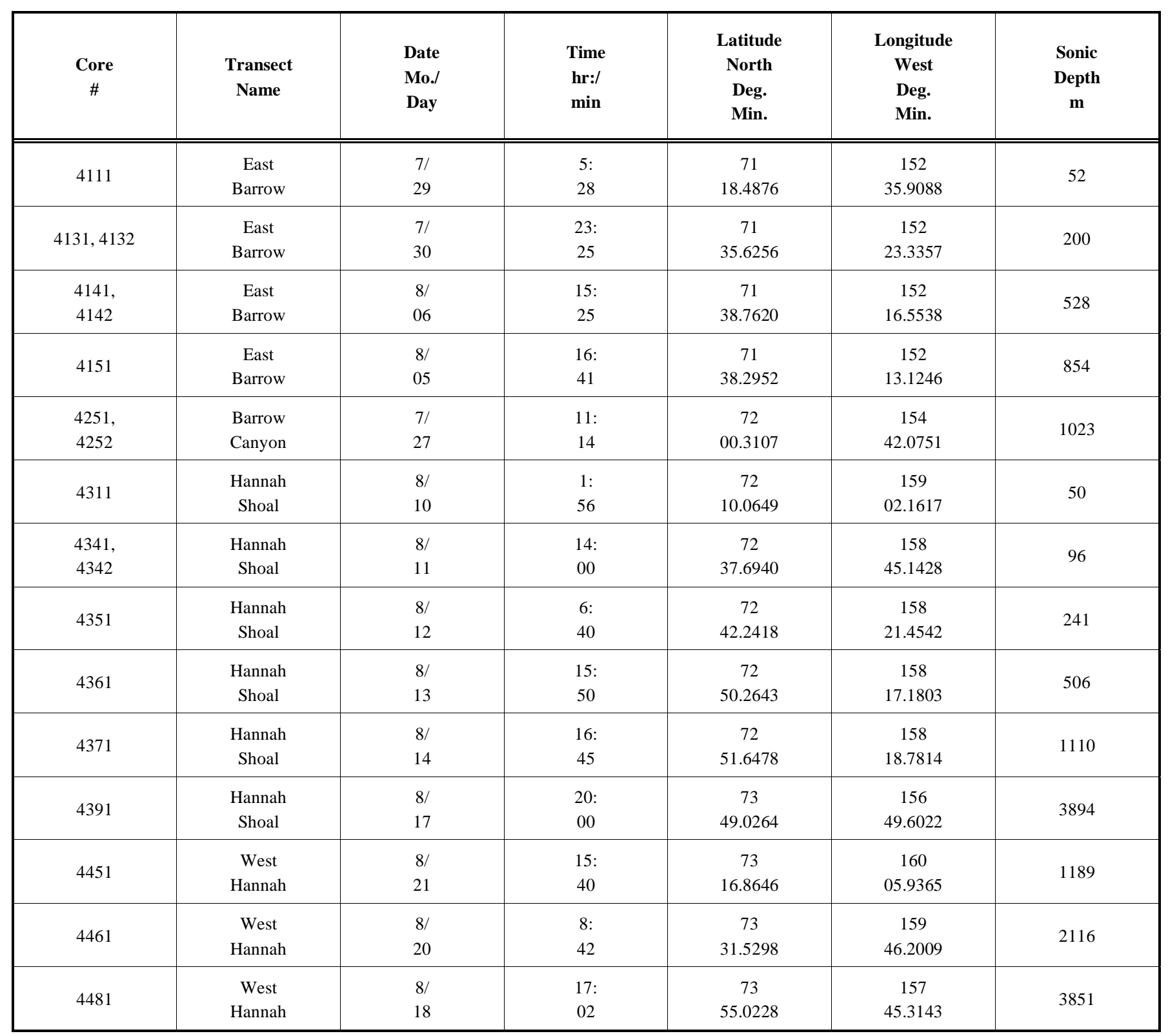

The gas samples were measured using a Perkin Elmer gas chromatograph (Sigma 2b) linked to a Balzers QMA 410, QMG 422 quadrapole mass spectrometer. In this system, gases were stripped from the seawater sample in a helium flow, passed through drying columns, through the gas chromatograph's hot wire detector (without the use of a separation column), and then passing the inlet port of the scanning mass-spectrometer. The total quantity of gas within a sample was evaluated based on the gas chromatographic output; while the mass spectrometric data were used to look in detail at the ratios of oxygen and nitrogen relative to argon. In detail, the procedure involved collecting a seawater sample from the cores or reservoirs in a gas-tight Valco 6 port valve with $4.40 \mathrm{ml}$ sample loop. This sample valve was then connected into the helium stripping stream and the connecting tubing purged of residual contaminating air. The analytical run began by injecting the seawater into the helium stream
(60 cc/min.), which forced the seawater into a $6 \mathrm{ml}$ stripper. Gases were expelled through a freezing moisture trap $\left(-80^{\circ}\right.$ C) and then into the hot wire detector of the Perkin Elmer Sigma $2 \mathrm{~B}$ chromatograph at $+80^{\circ} \mathrm{C}$. The reference helium flow in this detector was $20 \mathrm{cc} / \mathrm{min}$. The hot wire detector yielded a measure of total gas in the sample. Standards consisted of two types. Air standards were injected into the helium stream using a 8-port gas-tight valve located before the sample valve and having sample loop with volumes of either 10.11 or $100.0 \mu \mathrm{l}$. The air, from the exterior of the ship, was warmed to room temperature and dried using desiccant prior to loading into the valve's sample loops. The quantity of each ideal gas $\left(\mathrm{N}_{2}, \mathrm{O}_{2}\right.$ and $\left.\mathrm{Ar}\right)$ in these air standards was calculated from the loop volume, the valve temperature, and laboratory pressure. The second type of standard was deionized water which was equilibrated with the ship's air within the refrigerator containing the incubating cores. This water was 
sampled using the gas-tight Valco valve with $4.40 \mathrm{ml}$ sample loop. The quantities of $\mathrm{N}_{2}, \mathrm{O}_{2}$ and Ar within these deionized water standards were calculated based on the sample loop volume and the water's temperature using the solubility equations in [24]. The quantity of total gas represented the sum of these three gases. Drift of the hot wire detector response was evaluated based on air standards done at the beginning and end of the daily run. Core and reservoir samples were also corrected for the percentage recovery of the deionized water standards.

For the measurement of gas ratios, the results from the mass spectrometer were used. The gases passed the high vacuum entry port (Balzers UDV 040 inlet valve) of the quadrapole mass spectrometer after exiting the hot wire detector of the gas chromatograph. A portion of the gas stream was sucked into the high-vacuum mass spectrometer chamber and bled directly onto the ionizing coils. The mass spectrometer scanned the atomic mass unit (amu) range and recorded the electrical current output from the secondary electron multiplier detector at 4 mass settings, $28\left({ }^{14} \mathrm{~N}_{2}\right), 29$ $\left({ }^{15,14} \mathrm{~N}_{2}\right), 32\left({ }^{16} \mathrm{O}_{2}\right)$, and $40(\mathrm{Ar})$, spending $100 \mathrm{msec}$ at each amu and taking about 0.6 second per scan. Over the 2 minute time of a typical water sample peak, the instrument would obtain approximately 200 scans. The time course data for each amu was stored during the run. After the run, the ratios of current output were computed for the amu ratios of 28/40 $\left({ }^{14} \mathrm{~N}_{2} / \mathrm{Ar}\right)$ and $32 / 40\left({ }^{16} \mathrm{O}_{2} / \mathrm{Ar}\right)$, and these ratios were plotted versus run time. The plateau region of each sample peak was identified, and the average and standard deviation of the plateau region (typically about 10-20 scans) were used in subsequent calculations. Instrument drift was determined based on the air standards run at the beginning and the end of the day. Deionized water standards yielded ratios that averaged 101.5 percent of that expected for this water at the refrigeration temperature. Precision of replicate deionized water samples averaged $0.24 \%$ (standard error of the mean as a percentage of each mean). This precision was the same as that found in determining the average raw gas ratio from the plateau region of each sample peak, indicating that uncertainty was primarily determined in measuring an average ratio of a single sample.

Fluxes of silicate, total carbon dioxide, and total gas were calculated first by correction of the concentrations in the overlying water for dilution with previously introduced reservoir water. These concentrations were then regressed versus incubation time. The time rate of change was then multiplied by the ratio of volume of overlying water covering each core to the area of sediment in the subcores $(53.52$ $\mathrm{cm}^{2}$ ). The decrease in total gas concentration, assessed by gas chromatography, were primarily the result of the loss of oxygen content within the overlying waters, and hence a measure of oxygen flux by the core. For mass spectrometer determined ratios of gases $\left(28 / 40\right.$ being ${ }^{14} \mathrm{~N}_{2} / \mathrm{Ar}$ and $32 / 40$ being ${ }^{16} \mathrm{O}_{2} / \mathrm{Ar}$ ), fluxes were calculated by the same procedure. However, for these mass spectrometric data, the time rate of change of the ratios were multiplied by the argon concentration in the waters of each core, and then by the ratio of overlying water volume to sediment area. For $\mathrm{N}_{2}$, the calculated ${ }^{14} \mathrm{~N}_{2}$ concentration was divided by the isotopic proportion of ${ }^{14} \mathrm{~N} /\left({ }^{14} \mathrm{~N}+{ }^{15} \mathrm{~N}\right)$ in air $(0.9963)$ to obtain the total $\mathrm{N}_{2}$ flux. Fluxes from each core were listed in Table 2.
Table 2. Sediment-Water Fluxes of Total Carbon Dioxide, Silicate, Oxygen, and Nitrogen Gas Measured in Cores from Alaska's Northern Continental Break

\begin{tabular}{|c|c|c|c|c|}
\hline $\begin{array}{c}\text { Core } \\
\#\end{array}$ & $\begin{array}{c}\text { TCO } \\
\text { Flux }\end{array}$ & $\begin{array}{c}\text { SI } \\
\text { Flux }\end{array}$ & $\begin{array}{c}\mathbf{O}_{2} \\
\text { Flux }\end{array}$ & $\begin{array}{c}\mathbf{N}_{2} \\
\text { Flux }\end{array}$ \\
\hline \hline 4111 & 111 & 36.9 & -106 & 42.6 \\
\hline 4131 & 552 & 236 & -285 & 105.6 \\
\hline 4132 & 449 & 280 & -355 & 56.7 \\
\hline 4141 & 261 & 159 & -190 & 37.1 \\
\hline 4142 & 368 & 171 & -194 & 28.9 \\
\hline 4151 & 310 & 153 & -200 & 34.3 \\
\hline 4251 & 129 & 94.0 & -144 & 27.4 \\
\hline 4252 & 141 & 80.8 & -133 & 31.9 \\
\hline 4311 & 97.0 & 95.0 & -160 & 20.2 \\
\hline 4341 & 109 & 47.8 & -127 & 15.4 \\
\hline 4351 & 59.9 & 77.1 & -60.4 & 12.2 \\
\hline 4361 & 42.9 & 61.2 & -71.8 & 14.8 \\
\hline 4371 & nd & 46.9 & -104 & 33.6 \\
\hline 4391 & ---- & 1.9 & -9.0 & ---- \\
\hline 4451 & ---- & 41.3 & ---- & ---- \\
\hline 4461 & ---- & 23.8 & ---- & --- \\
\hline 4481 & ---- & 3.5 & --- & -- \\
\hline
\end{tabular}

Fluxes are in $\mu$ mole (of $\mathrm{C}, \mathrm{Si}, \mathrm{O}_{2}$, or $\mathrm{N}$ ) $\mathrm{m}^{-2} \mathrm{~h}^{-1}$. Not detectable is nd. Dashes indicate that the specific compound was not measured on this core.

\section{RESULTS}

\section{Fluxes of Total Carbon Dioxide}

This method of total carbon dioxide analysis was developed to measure small volumes of flux waters (1 $\mathrm{ml}$ of sample or less) with moderately high precision. The routine results indicate a precision averaging about $0.2 \%$ (standard error of the mean expressed as percentage of the mean value). This technique allowed measurement of fluxes from sediments as deep as $1000 \mathrm{~m}$ off the Alaskan shelf. The results indicate that highest fluxes of total carbon dioxide (about $500 \mu \mathrm{mol} \mathrm{m} \mathrm{m}^{-2} \mathrm{~h}^{-1}$ out of the sediments) occurred in the eastern most transect (East Barrow transect) offshore of the shelf break (Fig. 2A). The one set of cores from the Barrow Canyon transect had slightly lower fluxes than found on the East Barrow line; while the lowest fluxes were found all along the Hannah Shoal transect.

\section{Fluxes of Dissolved Oxygen}

Dissolved oxygen fluxes into the sediments were assessed by two methods, the decrease in the total gas concentration in the overlying waters with time as estimated from the gas chromatographic method and the decrease in the ${ }^{16} \mathrm{O}_{2}$ /Ar ratio with time based on the mass spectrometric tech- 

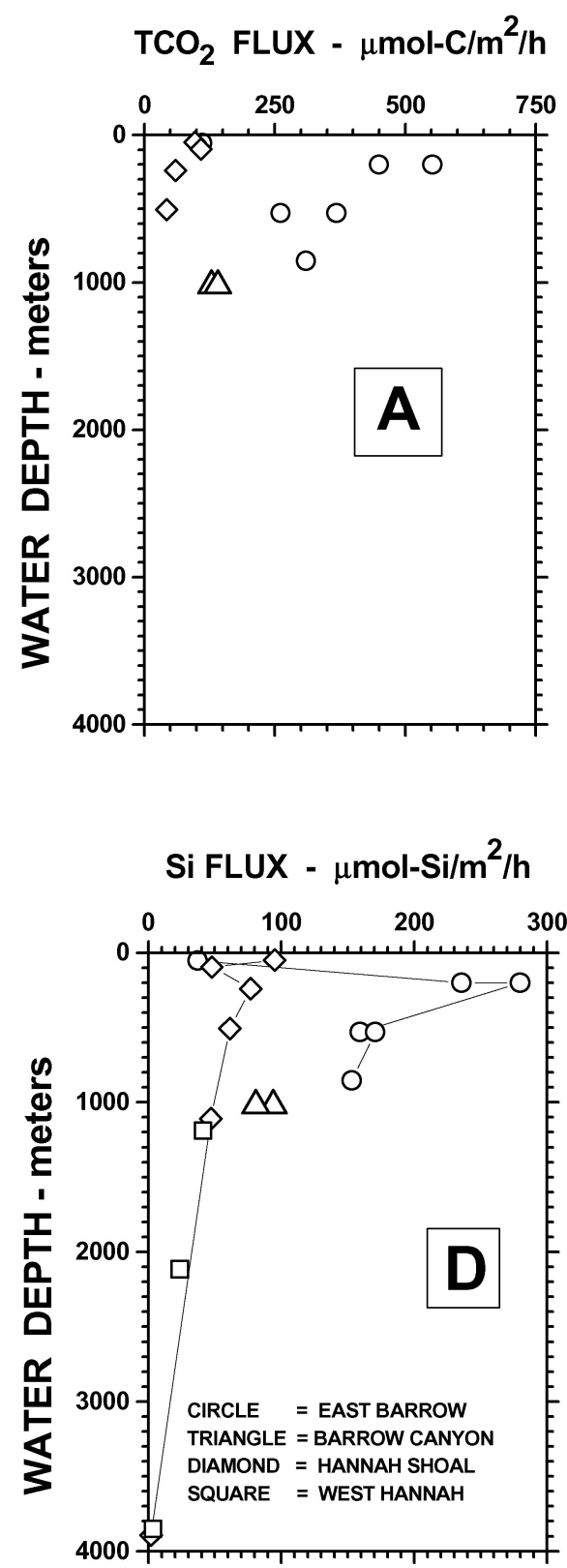
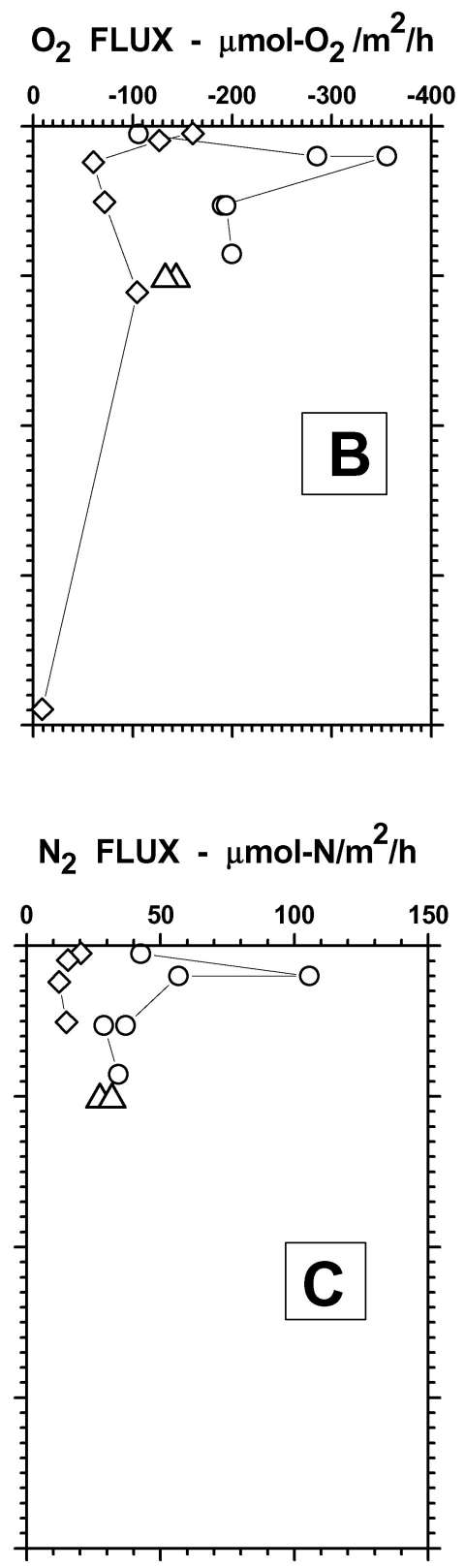

Fig. (2). (A) Sediment-water fluxes of total carbon dioxide versus water depth from the northern Alaskan continental margin. (B) Oxygen fluxes versus water depth. (C) Nitrogen gas fluxes versus water depth. (D) Dissolved silicate fluxes versus water depth.

nique. The two data sets permitted a quantitative check between the two approaches, and both yielded approximately the same results. Because the mass spectrometric results were more precise than the total gas content measured by the gas chromatograph, the time-regression of mass spectrometric oxygen content had better precision and oxygen fluxes were measurable at deeper locations than possible with the gas chromatographic method. In all subsequent discussions, the oxygen fluxes were those from the mass spectrometric ratios. Oxygen fluxes were greatest in stations deeper than the shelf break on the East Barrow transect (Fig. 2B). The pair of measurements on the Barrow Canyon transect were intermediate in value; while those on the Hannah Shoal were generally the lowest found (Fig. 2B). A linear regression of the oxygen fluxes onto the total carbon dioxide fluxes indicated a close relationship between the two $\left(r^{2}=0.82\right.$, Fig. 3$)$.
However, the intercept of the regression predicted a large oxygen flux $\left(-67.7 \mu\right.$ mol- $\left.\mathrm{O}_{2} \mathrm{~m}^{-2} \mathrm{~h}^{-1}\right)$ at the zero $\mathrm{TCO}_{2}$ flux. This intercept was statistically different from zero $(\mathrm{P}<=0.01)$ but is theoretically difficult to explain.

Looking at the data in more detail, at low fluxes of $\mathrm{TCO}_{2}$ ( $<150 \mu \mathrm{mol} \mathrm{TCO}_{2} \mathrm{~m}^{-2} \mathrm{~h}^{-1}$ ), the measured $\mathrm{O}_{2}$ fluxes approximated the Redfield ratio [25,26] using either the relationship of 106 moles of molecular oxygen to 106 moles of $\mathrm{TCO}_{2}$ (the Redfield ratio for aerobic respiration with release of unoxidized ammonium) or the relationship of $138 \mathrm{O}_{2}$ / $106 \mathrm{TCO}_{2}$ (including the oxidation of released ammonium to nitrate). At $\mathrm{TCO}_{2}$ fluxes greater than $150 \mu \mathrm{mol} \mathrm{m}{ }^{-2} \mathrm{~h}^{-1}$, oxygen fluxes were significantly less than either relationship would predict. This suggests that anaerobic oxidation of organic matter is more significant in the oxidation of sedimen- 


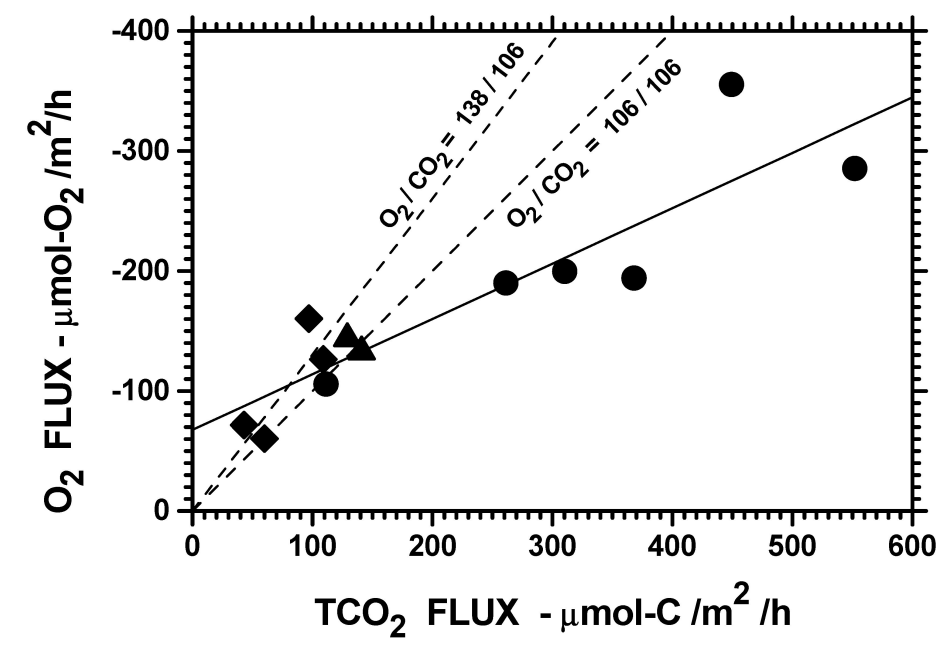

Fig. (3). Relationship between oxygen and total carbon dioxide fluxes from sediments. The linear regression (solid line) of the flux of oxygen $\left(\mathrm{F}_{\mathrm{O} 2}\right)$ onto the flux of $\mathrm{TCO}_{2}\left(\mathrm{~F}_{\mathrm{TCO} 2}\right)$ is $\mathrm{F}_{\mathrm{O} 2}=-0.461388 * \mathrm{~F}_{\mathrm{TCO} 2}-67.7367, \mathrm{n}=12, \mathrm{r}^{2}=0.8218$. The two dashed lines represent the Redfield ratio for organic matter respiration either with release of dissolved ammonium $\left(106 \mathrm{O}_{2} / 106 \mathrm{CO}_{2}\right)$, or with the oxidation of ammonium to nitrate $\left(138 \mathrm{O}_{2} / 106 \mathrm{CO}_{2}\right)$. Symbols follow those in Fig. (2).

tary organic matter at the more biologically-active stations. In the discussion section, these data will be shown to fit a published non-linear model of sedimentary oxygen and carbon fluxes. Here, fluxes of total carbon dioxide are taken as the more accurate measure of organic matter decay in these sediments, and in the subsequent discussion, the fluxes of nitrogen and silicate are compared solely with those of total carbon dioxide. The high-flux stations were solely those offshore of the shelf break on the East Barrow transect.

\section{Fluxes of Nitrogen Gas}

Nitrogen gas fluxes versus water depth of the cores are shown (Fig. 2C). These fluxes correlated well with $\mathrm{TCO}_{2}$ fluxes (Fig. 4). A linear regression of all the data yielded a slope of $0.127 \mu \mathrm{mol}-\mathrm{N} / \mu \mathrm{mol}-\mathrm{C}$, with a standard error of the slope being $+/-0.027 \mu$ mol-N/ $\mu$ mol-C. Although this slope was $84 \%$ of the stoichiometric predicted $\mathrm{N}$ regeneration flux using the Redfield ratio (16 atoms of nitrogen released per 106 atom of organic carbon oxidized), the slope was not significantly different from this ratio. Thus, the regression indicated that virtually all the regenerated nitrogen was exiting these cores as nitrogen gas.

\section{Fluxes of Dissolved Silicate}

Dissolved silicate fluxes were highest (ca $250 \mu \mathrm{mol} \mathrm{Si} \mathrm{m}{ }^{-2}$ $\mathrm{h}^{-1}$ ) on the East Barrow transect, offshore of the shelf break

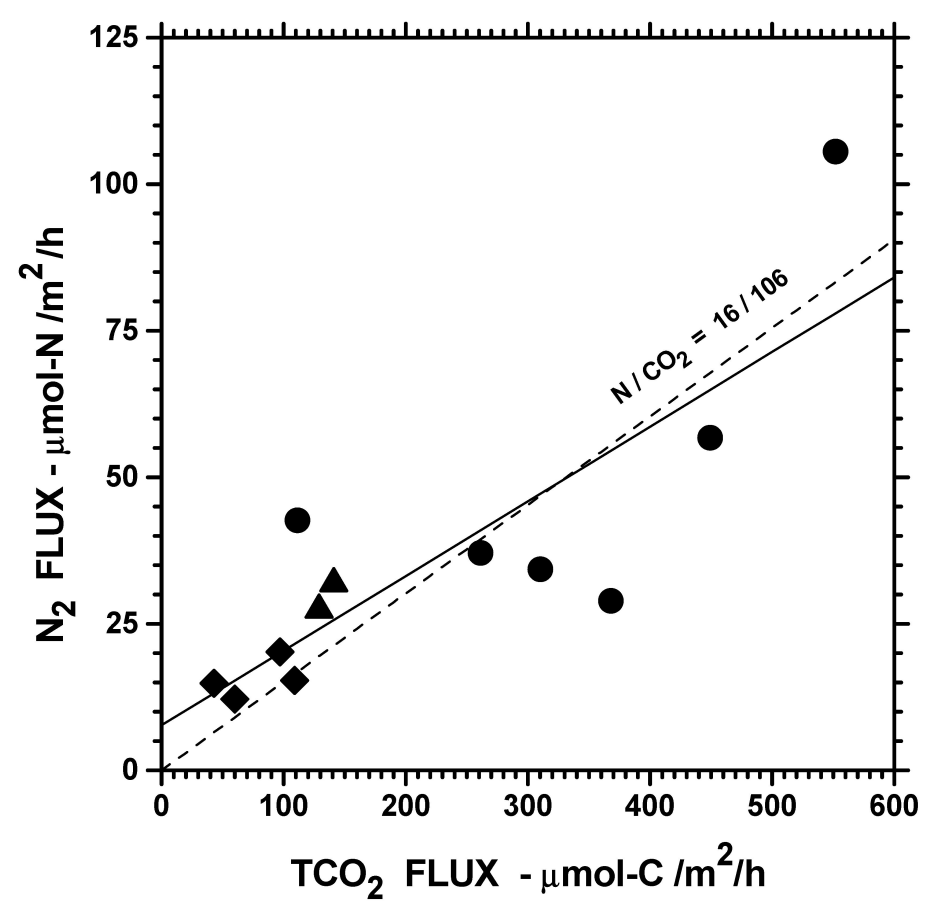

Fig. (4). Relationship of nitrogen gas fluxes and total carbon dioxide fluxes from sediments. The linear regression (solid line) of the flux of nitrogen $\left(\mathrm{F}_{\mathrm{N}}\right)$ onto the flux of $\mathrm{TCO}_{2}\left(\mathrm{~F}_{\mathrm{TCO} 2}\right)$ is $\mathrm{F}_{\mathrm{N}}=0.127352 * \mathrm{~F}_{\mathrm{TCO} 2}+7.6825, \mathrm{n}=12, \mathrm{r}^{2}=0.6923$. Symbols follow those in Fig. (2). 
(Fig. 2D). In the pair of cores from the Barrow Canyon transect, the fluxes were of intermediate value (ca $90 \mu \mathrm{mol} \mathrm{m}{ }^{-2}$ $\mathrm{h}^{-1}$ ); while on the Hannah Shoal line and deeper portions of the West Hannah transect, fluxes decreased approximately exponentially with water depth from high values of about 90 $\mu \mathrm{mol} \mathrm{m} \mathrm{m}^{-2} \mathrm{~h}^{-1}$ to values as low as $1.9 \mu \mathrm{mol} \mathrm{m} \mathrm{m}^{-2} \mathrm{~h}^{-1}$ at $3894 \mathrm{~m}$ water depth (Fig. 2D). The silicate fluxes were strongly correlated with the core's $\mathrm{TCO}_{2}$ fluxes (Fig. 5).

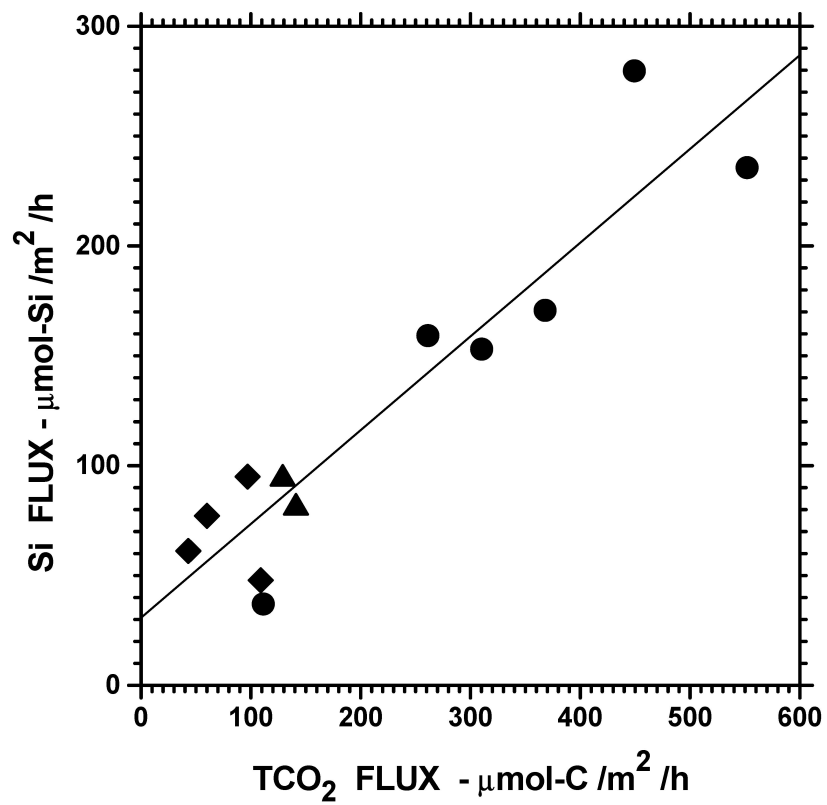

Fig. (5). Relationship of silicate fluxes and total carbon dioxide fluxes from sediments. The linear regression (solid line) of the flux of dissolved silica $\left(\mathrm{F}_{\mathrm{Si}}\right)$ onto the flux of $\mathrm{TCO}_{2}\left(\mathrm{~F}_{\mathrm{TCO} 2}\right)$ is $\mathrm{F}_{\mathrm{Si}}=$ $0.426634 * \mathrm{~F}_{\mathrm{TCO} 2}+30.8199, \mathrm{n}=12, \mathrm{r}^{2}=0.8640$. Symbols follow those in Fig. (2).

\section{DISCUSSION}

\section{Fluxes of Oxygen and Total Carbon Dioxide}

In this experiment, the fluxes of total carbon oxide, oxygen, nitrogen gas, and silicate were measured in summer along several transects from the shelf to the lower slope off the Chukchi and Beaufort Seas. Total carbon dioxide fluxes represent the carbon release from sediments due to organic matter oxidation in the sediments and the co-occurring carbonate dissolution [27]. The most common measure of benthic metabolism is oxygen consumption, but this measure may underestimate total sediment metabolism because of the potentially significant role of anaerobic respiration, primarily sulfate reduction $[9,27,28]$. The measured oxygen fluxes closely agreed with the fluxes of total carbon dioxide when $\mathrm{TCO}_{2}$ fluxes were less than $150 \mu \mathrm{mol} \mathrm{m} \mathrm{m}^{-2} \mathrm{~h}^{-1}$. In contrast, at $\mathrm{TCO}_{2}$ fluxes greater than $150 \mu \mathrm{mol} \mathrm{m} \mathrm{m}^{-2} \mathrm{~h}^{-1}$, oxygen fluxes significantly underestimated the $\mathrm{TCO}_{2}$ fluxes.

This type of non-linear relationship between oxygen and total carbon dioxide fluxes had been modeled [29]. The model considered typical aerobic sediments found in the deep sea and assumed that sediment burial of organic carbon represents only a small percentage of the total organic matter input to the sediments. The approach posited that if the respi- ratory demand by the organic matter influx (equivalent to the outward $\mathrm{TCO}_{2}$ flux measured off Alaska) was less than the potential supply of oxygen by diffusion and mixing into the sediment column, then the sediment column would remain primarily aerobic. The critical flux was defined as the magnitude of the organic matter influx that exactly balanced the maximum supply of dissolved oxygen. If organic matter fluxes exceeded this critical flux, oxygen would not support the reoxidation of all the incoming organic matter, so that at some depth, oxygen would be depleted and anaerobic conditions would be established as bulk sediment properties.

The mathematics of this model [29] showed that two properties of the organic matter influx ultimately influenced the development of anaerobic conditions. As described, the magnitude of the organic influx is important, but the reactivity of the organic matter also is significant. The reactivity of the organic matter oxidation rates was defined by the decay coefficient ( $b$ in units of $\mathrm{cm}^{-1}$ ) of the exponentially decreasing oxidation rate profile. If the organic matter was highly reactive, it could be decomposed in the sediment column relatively near the sediment surface where the supply of oxygen was potentially large. A sediment column receiving highly reactive material could remain aerobic with a significantly larger organic matter influx because the oxidation would occur near the sediment-water interface. In contrast, organic matter with smaller decay coefficient would not be oxidized as quickly and would survive longer and be buried deeper in the sediments. Increased depth of oxidation correlates with lesser fluxes of oxygen at depth. So with less reactive material, the critical flux would be much less than for a reactive organic material. These relationships are shown in Fig. (6). When the influx is below the critical flux, a 1:1 relationship occurs between the total carbon oxidation rate and the oxygen flux adjusted to the Redfield ratio. For a given exponential decay coefficient, the critical flux is the intersection of the 1:1 relationship and a non-linear curve defined by the decay coefficient (values of $0.1 \mathrm{~cm}^{-1}, 0.5 \mathrm{~cm}^{-1}$, and 2.5 $\mathrm{cm}^{-1}$ are drawn in Fig. (6)). Above the critical flux (which is fixed for each value of $b$ ), carbon oxidation by $\mathrm{O}_{2}$ is less than total sediment carbon oxidation.

The results from northern Alaska (Fig. 3) closely match these model results (Fig. 6). The cores with lower $\mathrm{TCO}_{2}$ fluxes approximate the 1:1 relationship, but the cores with larger $\mathrm{TCO}_{2}$ fluxes overlay the curvilinear relationship of the exponential decay coefficient of $2.5 \mathrm{~cm}^{-1}$. Note that past data from the southern and central Chukchi Sea fall along the same line [14]. With this decay coefficient, Fig. (6) would indicate that the critical organic matter influx for these cores was $86 \mu$ mol- $\mathrm{C} \mathrm{m}^{-2} \mathrm{~h}^{-1}\left(9.0 \mathrm{~g}-\mathrm{C} \mathrm{m}^{-2} \mathrm{y}^{-1}\right)$. Many of the cores had $\mathrm{TCO}_{2}$ fluxes exceeding this critical flux, so anaerobic conditions would likely be a common occurrence in these richer sediments. Many of the cores had a light brown nearsurface layer and black-gray muds below. At the five sites with the greatest $\mathrm{TCO}_{2}$ fluxes on the non-linear portion of the model, the average oxygen consumption accounted for only $49 \%$ of the total carbon dioxide release from the sediments.

\section{Fluxes of Nitrogen Gas and Total Carbon Dioxide}

The presence of anaerobic conditions would support the occurrence of sedimentary denitrification. Originally viewed 
as a process where nitrate and nitrite is reduced to molecular nitrogen under suboxic conditions [13,30,31], denitrification is now thought to be supplemented by anaerobic nitrate consumption by sulfide oxidizers [32,33], iron and manganese coupled nitrogen reactions [34,35], direct oxidation of ammonium with nitrite (anammox [36,37]), as well as other possible metabolisms [38-40]. All but the most anaerobic of these processes could be supported in the mixed aerobic/anaerobic conditions found in most of the cores. Even the cores with low $\mathrm{TCO}_{2}$ fluxes were relatively near the critical organic matter flux and could support micro environments of anaerobic or suboxic conditions with denitrification. The $\mathrm{N}_{2}$ /Ar ratios showed significant nitrogen gas fluxes (Fig. 4). Regression of the $\mathrm{N}_{2}$ fluxes onto $\mathrm{TCO}_{2}$ fluxes indicated that essentially all of the regenerated nitrogen exits the sediments as nitrogen gas.

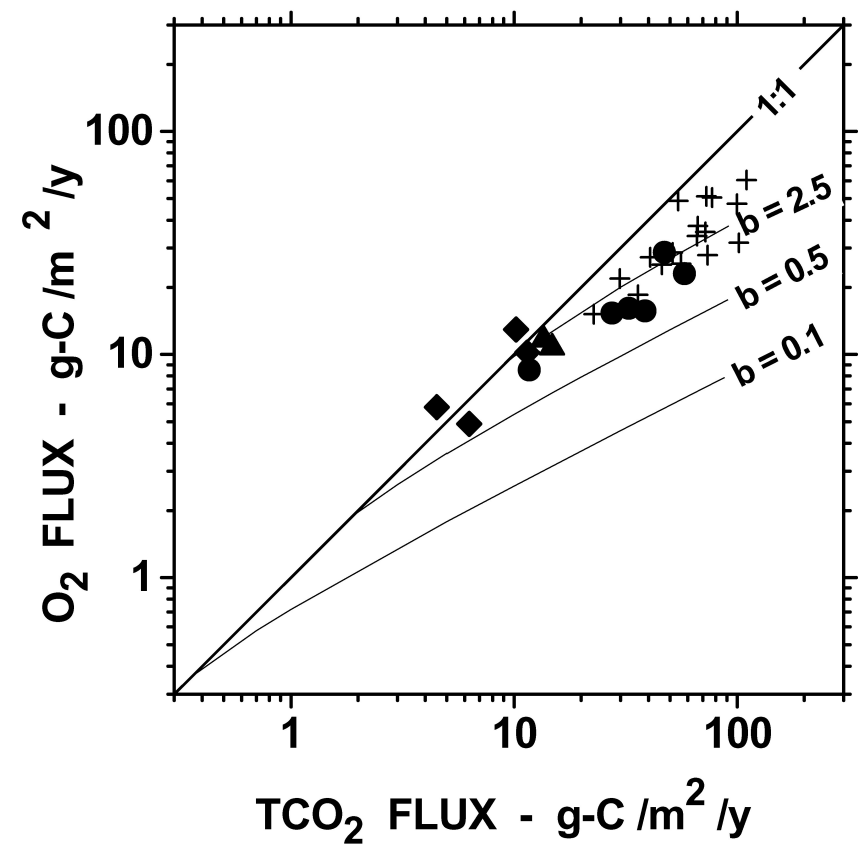

Fig. (6). Modeled relationship between sedimentary oxygen flux (converted to units of $\mathrm{CO}_{2}$ with the Redfield ratio of $138 \mathrm{O}_{2} / 106$ $\mathrm{CO}_{2}$ ) and the organic matter flux to the sediments. Model results [29] are described in the text. The listed values represent the decay coefficient $\left(\mathrm{b}\right.$ in $\left.\mathrm{cm}^{-1}\right)$ of the exponentially decreasing organic matter oxidation rate with depth in the sediments. Large dark symbols are the new Alaskan results which fit the model for $\mathrm{b}=2.5 \mathrm{~cm}^{-1}$. Crosses are additional Chukchi Sea sediment data [14].

\section{Distribution Silicate and Total Carbon Dioxide Fluxes}

Examination of the distributions of the silicate fluxes showed that the highest silicate fluxes were found just seaward of the shelf break, here taken as the $100 \mathrm{~m}$ depth contour. To better examine this offshore trend, the distance between each sediment station and nearest point on the shelf break was calculated. After combining the data from the two Barrow transects and then those from the two Hannah Shoal transects and plotting the silicate fluxes versus distance offshore, both combined transects show low fluxes at the shelf edge, highest fluxes within $20 \mathrm{~km}$ offshore of the $100 \mathrm{~m}$ depth contour, and an approximately exponential decrease in flux with increasing offshore distance (Fig. 7). A similar distribution was found in total carbon dioxide fluxes on the combined Barrow transect (Fig. 7). Importantly, these three distributions indicate the existence of a band of high remineralization rates located seaward of the continental shelf break.
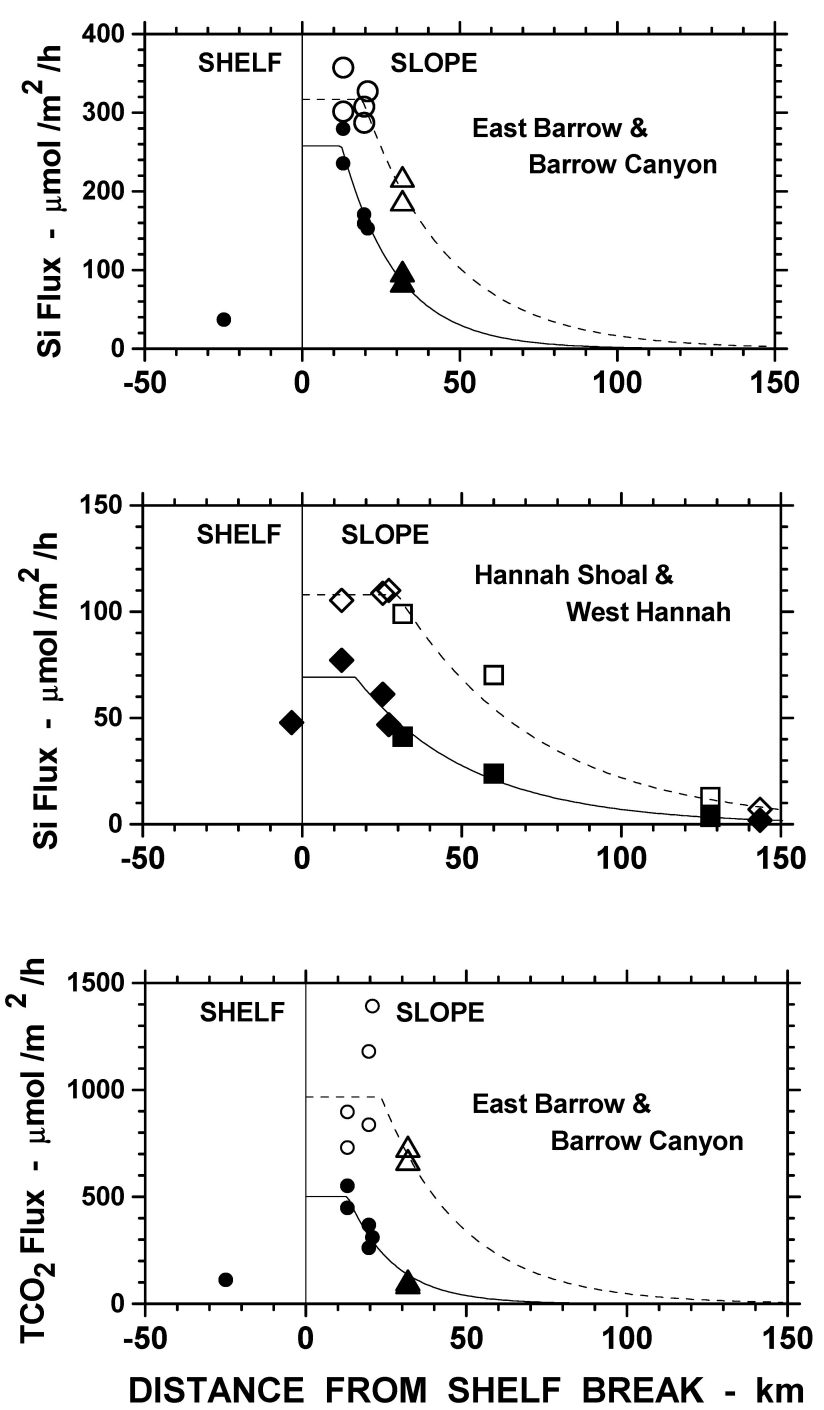

Fig. (7). Distributions of silicate and total carbon dioxide fluxes from the sediments and from both the sediments and waters below $100 \mathrm{~m}$ versus distance from the edge of the continental shelf. TOP: Silica data from the East Barrow (circles) and Barrow Canyon transects (triangles) considered together. MIDDLE: Silicate data from the Hannah Shoal (diamonds) and East Hannah transects (squares) were combined. BOTTOM: $\mathrm{TCO}_{2}$ data from the East Barrow (circles) and Barrow Canyon transects (triangles) were combined. Solid symbols and solid lines are the sediment data and their fits. Open symbols and dashed lines are the sums of the sediment and water column remineralization and their fits. Horizontal averages (0-30 $\mathrm{km}$ ) were evaluated by integrating the solid and dashed lines.

The sedimentary silicate fluxes seemed comparable to other productive continental margins and appeared high given the low productivity of the northern Alaskan shelf (ca $\left.50 \mathrm{~g}-\mathrm{C} \mathrm{m}^{-2} \mathrm{y}^{-1}[16,17,22]\right)$. For example, sediment dissolved silicate fluxes from the rich Washington state upper conti- 
nental slope $(150-700 \mathrm{~m})$ ranged between 79 and $227 \mu \mathrm{mol}$ $\mathrm{Si} \mathrm{m} \mathrm{m}^{-2}$ and averaged $122 \mu \mathrm{mol} \mathrm{Si} \mathrm{m}{ }^{-2} \mathrm{~h}^{-1}$ when one anomalous station was excluded [5]. The Washington shelf values fall between the ranges found on the East Barrow transect and the Hannah Shoal transect. The primary productivity off Washington state generally exceeded $700 \mathrm{~g}-\mathrm{C} \mathrm{m}^{-2}$ $\mathrm{y}^{-1}$ [41], so the similarities in sedimentary silicate fluxes suggests that relatively high productivities would have been required to support the measured sediment fluxes off Alaska.

In order to explore this discrepancy, the average silicate flux out of the sediments in the upper slope region was estimated for the two combined transects. Then, the question was asked, How much diatom productivity would be required in waters directly overlying these sediments in order to match the sediment fluxes. For these calculations, the offshore distribution of the silicate flux was integrated by interpolating the average of the high inner-slope fluxes from the shelf break to the distance of the maxima and then integrating the exponential decrease from this maxima to $30 \mathrm{~km}$ offshore (Fig. 7). On the two combined transects, the average of these integrals were 202 and $64.1 \mu$ mol-Si m${ }^{-2} \mathrm{~h}^{-1}$ (Table 3). Considering permanent burial of particulate silica to be small, the sedimentary silica dissolution would balance the corresponding input of sinking diatom material. Using the atomic Redfield ratios of $\mathrm{N} / \mathrm{C}=16 / 106$ and $\mathrm{N} / \mathrm{Si}=1 / 1$ for diatom growth $[42,43]$, these flux averages would have required an average diatom production of 141 and $44.6 \mathrm{~g}-\mathrm{C} \mathrm{m}^{-2}$ $\mathrm{y}^{-1}$ on the two combined transects, respectively. To convert the sedimentary fluxes to levels of annual productivity, these calculations assumed no change in sedimentary fluxes over the annual cycle. The values would be lowered if the annual cycle of sediment remineralization varied seasonally. However, winter-summer differences were not seen in sedimen-

Table 3. Silicate and Total Carbon Dioxide Fluxes from Sediments, Vertical Fluxes Supporting Remineralization in Both Water Column Below $100 \mathrm{~m}$ and Sediments, and Estimates of Annual Sinking Exports and Productivities in the Upper $100 \mathrm{~m}$

\begin{tabular}{|c|c|c|}
\hline Flux Type & $\begin{array}{c}\text { East Barrow } \\
\text { Transect }\end{array}$ & $\begin{array}{c}\text { Hannah Shoal } \\
\text { Transect }\end{array}$ \\
\hline Si Flux (sediments) ${ }^{\mathrm{a}}$ & 202 & 64.1 \\
\hline $\mathrm{TCO}_{2}$ Flux (sediments) ${ }^{\mathrm{a}}$ & 384 & 108 \\
\hline Si Flux below $100 \mathrm{~m}^{\mathrm{b}}$ & 297 & $---{ }^{f}$ \\
\hline $\mathrm{TCO}_{2}$ Flux below $100 \mathrm{~m}^{\mathrm{b}}$ & 941 & $--{ }^{f}$ \\
\hline Diatom Export $^{\mathrm{c}}$ & 207 & 75.2 \\
\hline Carbon Export ${ }^{\mathrm{d}}$ & 98.9 & --- \\
\hline Primary Production ${ }^{\mathrm{e}}$ & 205 & --- \\
\hline
\end{tabular}

Fluxes are in units of $\mu \mathrm{mol} \mathrm{m} \mathrm{m}^{-2} \mathrm{~h}^{-1}$. Sinking exports at $100 \mathrm{~m}$ and euphotic zone production are in units of $\mathrm{g} \mathrm{C} \mathrm{m}^{-2} \mathrm{y}^{-1}$. (a) The integral average of measured sediment fluxes versus distance from the shelf break (100 m depth) to $30 \mathrm{~km}$ off the shelf. (b) The estimated remineralization by both the sediments and waters below $100 \mathrm{~m}$ averaged over the $0-30 \mathrm{~km}$ slope region. (c) The diatom production required to match the silica fluxes in both the sediments and waters. (d) The annual export flux out of the surface waters. (e) Total primary productivity was calculated using equation 2 , and results for individual stations were averaged. (f) The exponential decrease with distance offshore could not be evaluated because too few $\mathrm{TCO}_{2}$ flux data were measured. tary $\mathrm{O}_{2}$ and $\mathrm{TCO}_{2}$ fluxes in the northern Chukchi Sea [14]. Nevertheless, if the sediments had $50 \%$ lower silicate fluxes over 6 months of winter, then the annual average would be $75 \%$ of the above estimates. Again, this set of calculations asks simply how much diatom productivity would be required in the waters directly overhead of the upper slope region just to provide the particulate silica that was remineralized in the sediments.

The estimates of diatom primary production would be increased if the resolubilization of silica within the water column were included. Deep-sea sediment trap results have indicated that silica dissolution occurs as biogenic material sinks through the water column [44-46]. Over all, 75\% of the particulate silica exiting the mixed layer may redissolve in the deep sea prior to reaching the sediments [47]. Furthermore, sediment traps at $4000 \mathrm{~m}$ collect about $75 \%$ of the amount of biogenic silica which is caught in traps at $1000 \mathrm{~m}$ [45]. Here, a common relationship in studies of sinking organic carbon [48],

$$
\mathrm{J}_{\mathrm{Z}}=\mathrm{J}_{\mathrm{o}}\left(\mathrm{Z} / \mathrm{Z}_{\mathrm{o}}\right)^{\mathrm{b}}
$$

was used. The flux at depth, $\mathrm{Z}$, is $\mathrm{J}_{\mathrm{z}}$. The sinking flux out of the surface layer is $J_{0}$, and the bottom depth of the surface layer from which export is calculated is $Z_{0}$ (typically $100 \mathrm{~m}$ ). A value of -0.3543 of the exponent, $b$, yields a $J_{z}$ at $5000 \mathrm{~m}$ of $25 \%$ of $\mathrm{J}_{0}$, corresponding with the results of [47]. Also, this exponent gives a value of the flux at $4000 \mathrm{~m}$ which is $61 \%$ of the value of the flux at $1000 \mathrm{~m}$, close to the sediment trap results of [45].

This equation was used to estimate the approximate magnitude of the remineralization occurring in the water column. First, the sinking flux of silica at $100 \mathrm{~m}$ was calculated for each core (equation 1) using the sediment flux and the sediment depth. Then, the exponential relationship with distance offshore was reevaluated and reintegrated over the $30 \mathrm{~km}$ from the shelf break. The resulting remineralization of silica from both the sediments and the waters below 100 $\mathrm{m}$ would be 297 and $108 \mu \mathrm{mol}-\mathrm{Si} \mathrm{m}^{-2} \mathrm{~h}^{-1}$ on the two combined transects (Table 3 ). The corresponding diatom production in the surface layer would have needed to be 207 and $75.2 \mathrm{~g}-\mathrm{C} \mathrm{m} \mathrm{m}^{-2}$, respectively. Of course, the total primary production would exceed this, both because of growth of non-siliceous phytoplankton and because of regenerated production [49]. Thus, the silicate fluxes measured on the northern Alaskan upper slope indicate a more productive ecosystem than earlier reports have indicated.

These calculations were repeated based on the $\mathrm{TCO}_{2}$ fluxes from the combined Barrow transect (Table 3, Fig. 7). Integrated over the $30 \mathrm{~km}$ north of the shelf break, the average sedimentary $\mathrm{TCO}_{2}$ flux was $384 \mu$ mol- $\mathrm{C} \mathrm{m}^{-2} \mathrm{~h}^{-1}$ (Table 3). To correct for the respiration occurring during sinking to the sediments, two different relationships were used. First, based on equation 1 and the coefficient of 0.70 as determined in sediment trap experiments $[48,50]$, remineralization from both the sediment and water column deeper than $100 \mathrm{~m}$ would be $941 \mu$ mol-C m$~^{-2} \mathrm{~h}^{-1}$. This export is equivalent to $98.9 \mathrm{~g}-\mathrm{C} \mathrm{m}^{-2} \mathrm{y}^{-1}$ (Table 3). Alternatively, a direct relationship between overlying primary productivities $(\mathrm{P})$ and deep-sea benthic oxygen fluxes $\left(\mathrm{R}_{\mathrm{c}}\right)$ was

$$
\mathrm{R}_{\mathrm{c}}=\mathrm{m} * \mathrm{Z}^{\mathrm{n}} \mathrm{P}^{\mathrm{q}}
$$


where $\mathrm{R}_{\mathrm{c}}$ and $\mathrm{P}$ are in units of $\mathrm{g}-\mathrm{C} \mathrm{m}^{-2} \mathrm{y}^{-1}, \mathrm{Z}$ is water depth $(\mathrm{m})$, and the coefficients were $\mathrm{m}=19.654, \mathrm{n}=-0.93641$, $\mathrm{q}=1.1395$ [29]. Based on the measured $\mathrm{TCO}_{2}$ fluxes and their water depths, the average total primary productivity for the $30 \mathrm{~km}$ band of continental slope would have been $205 \mathrm{~g}-\mathrm{C}$ $\mathrm{m}^{-2} \mathrm{y}^{-1}$ (Table 3). Thus, both of these algorithms based on total carbon dioxide fluxes indicate that overlying productivity on the combined Barrow transect would have been greater in the slope region than on the shelf. All three estimates (diatom production, carbon flux, and primary production) from the Barrow transect indicate that the slope region would need to be have productivities of ca $200 \mathrm{~g}-C ~ m^{-2} \mathrm{y}^{-1}$ in order to be the sole provider in maintaining the observed sedimentary fluxes. On the combined Hannah Shoal transect, a diatom productivity of $75 \mathrm{~g}-\mathrm{C} \mathrm{m}^{-2} \mathrm{y}^{-1}$ would be required.

\section{Shelf Export or Slope Productivity?}

The sediment flux data indicate a rich band of sediments on the upper slope off the north coast of Alaska. The above calculations suggest that productivities required to support these fluxes would need to be much greater than that found on the outer shelf. The estimated values of productivity assumed that the sinking flux came from surface waters on the upper slope. But it is equally possible that this band of biogenically rich sediments on the upper continental slope may be maintained by a combination of upper slope productivity as well as offshelf export of some fraction of the productivity of the shelf ecosystem.

Past research employed the definition of export as the difference between organic matter oxidation by all trophic levels on the shelf and the net primary productivity of the shelf area [9,51]. The northern Chukchi has been suggested to be a site of significant export, but studies on other shelves have demonstrated that initial perceptions are not always supported by quantitative evaluations. The New York Bight was originally thought to be a site of seaward export $[3,52]$ but after detailed examination, it was found to export less than $10 \%$ of its annual productivity [51,53], with an approximate balance between the measured annual primary productivity and consumption in the water column and sediments on the shelf [54]. A balance was also found between the sinking carbon inputs to the sediments estimated from annual productivity and sediment metabolism in the large, semi-enclosed Gulf of Maine [9], indicating no measurable large-scale export. The Gulf of Maine might be analogous in size to the Chukchi Sea as a whole, suggesting proportionally little export from the Chukchi Sea as a whole. Note that the most productive hot spot of the Chukchi Sea is just north of the Bering Strait [15,18], over $700 \mathrm{~km}$ south of the northern continental margin. In contrast to large shelf seas, a comparison of productivities and sediment metabolism rates on the narrow and dynamic Washington state continental shelf suggested $20-50 \%$ of the overall productivity was exported from that shelf [9]. In such a high export environment, shifting the suspended and settling organic material seaward over the slope would be expected to augment deposition of biogenic materials to the slope sediments. Even though horizontal shelf export may be significant off Washington state, the distribution of silicate fluxes on the Washington continental slope shows no development of a shelfedge silicate-rich band [5,9].
Would a similar horizontal shift of sinking material from the shelf to the slope explain the band of high silicate and inorganic carbon regeneration found seaward of the Chukchi and Beaufort shelf edges? To explore this, the unexplained productivity of the upper slope on the Barrow transects was defined as the difference between the estimated requirement of $200 \mathrm{~g}-\mathrm{C} \mathrm{m}^{-2} \mathrm{y}^{-1}$ and the nominal productivity of $50 \mathrm{~g}-\mathrm{C} \mathrm{m}^{-2}$ $\mathrm{y}^{-1}$. Over the area of the $30 \mathrm{~km}$ wide upper slope band by a kilometer length of shelf edge, the unexplained production would equal $4.5 \times 10^{9}{\mathrm{~g}-C ~ y^{-1}}^{(}(200-50) \mathrm{g}^{-} \mathrm{C} \mathrm{m}^{-2} \mathrm{y}^{-1}$ x $30 \mathrm{~km}$ x $1 \mathrm{~km} \mathrm{x} 10^{6} \mathrm{~m}^{2} / \mathrm{km}^{2}$ ). With a shelf exporting $25 \%$ of its productivity of $50 \mathrm{~g}-\mathrm{C} \mathrm{m}^{-2} \mathrm{y}^{-1}, 360 \mathrm{~km}^{2}$ of the shelf would be needed to match the $4.5 \times 10^{9} \mathrm{~g}^{-\mathrm{C} \mathrm{y}^{-1}}$. Considering a northsouth oriented slice of the shelf and slope that is $1 \mathrm{~km}$ across in its east-west orientation, the width of the shelf needed for this export $(360 \mathrm{~km})$ would be nearly half of the width of the Chukchi Sea. Although organic matter export over such long distances is possible, the exported fraction would undergo remineralization during its horizontal transit as well as during its sinking to the site of sedimentary deposition. Because the horizontal and vertical scales are so radically different (the mid-point of each $30 \mathrm{~km}$ upper slope band has a depth of about $500 \mathrm{~m}$ ), it could be envisioned that degradation during horizontal transit would greatly exceed the degradation estimated using equations 1 and 2 for sinking. Furthermore, if this horizontal transport occurs via a sequence of deposition-resuspension events, degradation while in the sediments might be even more significant than during water circulation alone. The nitrogen gas fluxes measured here show that essentially all the regenerated nitrogen exiting the sediments is $\mathrm{N}_{2}$ and is unavailable for regenerated productivity. If the exported organic material spends time in the sediments, the portion that decays within the sediments would not be regenerating usable nitrogen. Thus, by the time the material reached the final sedimenting environment (the upper slope biogenic band), the exported material would likely be considerably more refractory than the original produced organic material [55] and would contribute significantly less to the remineralization of the upper slope sediments. Consequently, if the northern shelf productivity is as low as previously thought, the data presented here suggests that it would be difficult to define a productivity hot-spot on the shelf which would be rich enough and close enough to the shelf edge to be the source for the upper slope biogenic band.

The simplest alternate hypothesis to the offshelf transport hypothesis is that the slope environment itself is a zone of active primary productivity. Barrow Canyon appears to be a site of frequent upwelling $[56,57,58,59]$, and significant primary production rates have previously been found there $[60,61]$. Also, upwelling events have been found along the Beaufort shelf edge $[58,62]$. Considering that few studies of the summer-time hydrography of the Beaufort shelf-break have occurred due to difficulty of scientific access through the pack ice, the proportion of publications which mention upwelling suggests a potentially frequent process at the Beaufort shelf edge. The upwelling events are typically observed by tracking the distinctive salinities and temperatures of the subsurface Halocline and Atlantic Water layers normally located off the shelf at depths of about 100-200 m $[56,57,58,59]$. These same waters are a year-round nutrientrich source $[58,63]$. Early studies of upwelling off northwest Africa showed that upwelling favorable winds not only gen- 
erated inner shelf upwelling but also induced events at the shelf break [64]. Similar summer-time events along the Chukchi and Beaufort Sea shelf break would support enhanced productivity in the upper slope region and could explain the distributions of sedimentary silicate and total carbon dioxide fluxes.

\section{CONCLUSIONS}

The relationship between fluxes of dissolved oxygen and $\mathrm{TCO}_{2}$ follow a non-linear model of sediment carbon oxidation in which aerobic sediments, having a linear relationship between oxygen consumption and total carbon dioxide release, should be maintained below $86 \mu \mathrm{mol} \mathrm{TCO}_{2} \mathrm{~m}^{-2} \mathrm{~h}^{-1}$. Above this threshold, anaerobic conditions in the bulk sediments intensify with increased organic matter loading, and oxygen fluxes increasingly underestimate $\mathrm{TCO}_{2}$ fluxes. The nitrogen gas fluxes directly correlated with the fluxes of total carbon dioxide. The regression slope was not significantly different than the Redfield N:C ratio, indicating that essentially all nitrogen regenerated by these sediments returned to the overlying waters as nitrogen gas. Also, silicate fluxes were well correlated with the $\mathrm{TCO}_{2}$ fluxes. Geographically, highest fluxes were observed on the cross-slope transects at $152^{\circ}$ and $155^{\circ}$ west longitude. Lower fluxes were found on transects at $159^{\circ}$ and $161^{\circ}$ west longitude. On each transect, highest fluxes were generally found within $20 \mathrm{~km}$ seaward of the $100 \mathrm{~m}$ continental shelf break. The upper slope silicate fluxes were comparable in magnitude to productive continental margins off the west coast of the U.S. For a $30 \mathrm{~km}$ band seaward of the shelf break, diatom productivity, vertical carbon export at $100 \mathrm{~m}$, and euphotic zone productivity would need to greatly exceed currently accepted levels for the northern Alaskan region. Off-shelf export of a fraction of the shelf's productivity as sinking organic material could supplement the vertical fluxes on the upper slope, but the low productivity on the Alaskan shelves likely would be insufficient to match the magnitude of the upper slope sediment fluxes. Previous literature has reported shelf-break upwelling which could support enhanced productivity in the upper slope region.

\section{ACKNOWLEDGEMENTS}

This work was supported by NSF grants 9905951, 0125306, and 0125313 to the author. The author thanks the officers, and crew of the USGC Healy for their assistance during this field work. This is contribution number 200801 from Bigelow Laboratory for Ocean Sciences.

\section{REFERENCES}

[1] Ryther JH. Photosynthesis and fish production in the sea. Science 1969; 166: 72-6.

[2] Eppley RW, Peterson BJ. Particulate organic matter flux and planktonic new production in the deep ocean. Nature 1979; 282: 677-80.

[3] Walsh JJ, Premuzic ET, Gaffney JS, et al. Organic storage of $\mathrm{CO}_{2}$ on the continental slope off the mid-Atlantic Bight, the southeastern Bering Sea, and the Peru coast. Deep-Sea Res 1985; 32: 85383.

[4] Walsh JJ. Importance of continental margins in the marine biogeochemical cycling of carbon and nitrogen. Nature 1991; 350: 53-5.

[5] Devol AH, Christensen JP. Benthic fluxes and nitrogen cycling in sediments of the continental margin of the eastern North Pacific. J Mar Res 1993; 51: 345-72.
[6] Rowe GT, Clifford CH, Smith KL Jr. Nutrient regeneration in sediments off Cap Blanc, Spanish Sahara. Deep-Sea Res 1977; 24: 57-64.

[7] Pamatmat MM, Banse K. Oxygen consumption by the seabed. II. In situ measurements to a depth of $180 \mathrm{~m}$. Limnol Oceanogr 1969; 14: $250-59$.

[8] Smith KL Jr, White GA, Laver MB. Oxygen uptake and nutrient exchange in sediments measured in situ using a free vehicle grab respirometer. Deep-Sea Res 1979; 26: 337-46.

[9] Christensen JP. Sulfate reduction and carbon oxidation rates in continental shelf sediments, an examination of off-shelf carbon transport. Cont Shelf Res 1989; 9: 223-46.

[10] Christensen JP. Carbon export from continental shelves, denitrification and atmospheric carbon dioxide. Cont Shelf Res 1994; 14: 547-76.

[11] Delwiche CC. In: Delwiche CC, Ed. The nitrogen cycle and nitrous oxide. Denitrification, Nitrification and Atmospheric nitrous oxide. J. Wiley and Sons, New York, NY 1981; 1-15.

[12] Codispoti LA, Brandes JA, Christensen JP, et al. The oceanic fixed nitrogen and nitrous oxide budgets: Moving targets as we enter the anthropocene? Scientia Marina 2001; 65 (2): 85-105.

[13] Christensen JP, Murray JW, Devol AH, Codispoti LA. Denitrification in continental shelf sediments has major impact on the oceanic nitrogen budget. Global Biogeochem Cycles 1987; 1: 97-116.

[14] Devol AH, Codispoti LA, Christensen JP. Summer and winter denitrification rates in western Arctic shelf sediments. Cont Shelf Res 1997; 17: 1029-50.

[15] Sambrotto RN, Goering JJ, McRoy CP. Large yearly production of phytoplankton in the western Bering Strait. Science 1984; 225: 1147-50.

[16] Hameedi JJ. Aspects of water column primary productivity in Chukchi Sea during summer. Mar Biol 1978; 48: 37-46.

[17] Cota GF, Pomeroy LR, Harrison WG, et al. Nutrients, primary production, and microbial heterotrophy in the southeastern Chukchi Sea: Arctic summer nutrient depletion and heterotrophy. Mar Ecol Prog Ser 1996; 135: 247-58.

[18] Grebmeier JM, McRoy PC. Pelagic-benthic coupling on the shelf of the northern Bering and Chukchi Seas. III. Benthic food supply and carbon cycling. Mar Ecol Prog Ser 1989; 53: 79-91.

[19] Dunton KR, Goodall JL, Schonberg SV, Grebmeier JM, Maidment DR. Multi-decadal synthesis of benthic-pelagic coupling in the Western Arctic: role of cross-shelf advective processes. Deep-Sea Res II 2005; 52: 3462-77.

[20] Coachman LK, Aagaard K. In: Herman Y, Ed. Physical Oceanography of Arctic and Subarctic Seas. Marine Geology and Oceanography of the Arctic Seas. Springer-Verlag New York, NY 1974; 172.

[21] Weingartner TJ, Aagaard K, Woodgate R, Danielson S, Sasaki Y, Cavalieri D. Circulation on the north central Chukchi Sea shelf. Deep-Sea Res II 2005; 53: 3150-74.

[22] Chen M, Huang YP, Guo LD, et al. Biological productivity and carbon cycling in the Arctic Ocean. Chinese Sci Bull 2002; 47 (12): 1037-40.

[23] Strickland JDH, Parsons TR. A practical handbook of seawater analysis, $2^{\text {nd }}$ edition, Bull Fish Res Board Can 1972; 167: 1-310.

[24] Weiss RF. The solubility of oxygen, nitrogen, and argon in water and seawater. Deep-Sea Res 1970; 17: 721-35.

[25] Redfield A, Kethcum BH, Richards FA. In: Hill MN, Ed. The influence of organisms on the composition of seawater. The Sea. Academic Press, New York, NY 1963; 26-77.

[26] Richards FA. In: Riley JP, Skirrow G, Eds. Anoxic basins and fjords. Chemical Oceanography. Academic Press, London, England 1965; 1: 611-45.

[27] Berelson WM, McManus J, Coale KH, et al. Biogenic matter diagenesis on the sea floor: A comparison between two continental margin transects. J Mar Res 1996; 54: 731-62.

[28] Jorgensen BB. Bacterial sulfate reduction within reduced microniches of oxidized marine sediments. Mar Biol 1977; 41: 7-17.

[29] Christensen JP. A relationship between deep-sea benthic oxygen demand and oceanic primary productivity. Oceanologica Acta 2000; 23 (1): 65-82.

[30] Jenkins MC, Kemp WH. The coupling of nitrification and denitrification in two estuarine sediments. Limnol Oceanogr 1984; 29: 60919. 
[31] Vanderborght JP, Billen G. Vertical distributions of nitrate concentrations in interstitial waters of marine sediments with nitrification. Limnol Oceanogr 1975; 20: 953-61.

[32] Fossing H, Gallardo VA, Jorgensen BB, et al. Concentration and transport of nitrate by the mat-forming sulpher bacterium Thioploca. Nature 1995; 374: 713-5.

[33] Schulz HN, Brinkhoff T, Ferdelman TG, Marine MH, Teske A, Jorgensen BB. Dense populations of a giant sulfur bacterium in Namibian Shelf sediments. Science 1999; 284: 493-5.

[34] Luther GW III, Sundby B, Lewis BL, Silverberg N. Interactions of manganese with the nitrogen cycle: alternative pathways to dinitrogen. Geochim Cosmochim Acta 1997; 61: 4043-52.

[35] Hulth S, Aller RC, Gilbert F. Coupled anoxic nitrification/ manganese reduction in marine sediments. Geochim Cosmochim Acta 1999; 63: 49-66

[36] Kuypers MM, Lavik MG, Thamdrup B. In: Jeretin LN, Ed. Anaerobic ammonium oxidation in the marine environment. Past and Present Water Column Anoxia. NATO Science Series IV. Earth and Environmental Sciences, Springer, Dordrecht, 2006; 64: 311 35.

[37] Thamdrup B, Dalsgaard T. Production of $\mathrm{N}_{2}$ through anaerobic ammonium oxidation coupled to nitrate reduction in marine sediments. Applied Environ Micro 2002; 8: 1312-8.

[38] Brandes JA, Devol AH. Simultaneous nitrate and oxygen respiration in coastal sediments: evidence for discrete diagenesis. J Mar Res 1995; 53: 771-97.

[39] Middelburg JJ, Soetaert K, Herman PMJ, Heip CHR. Denitrification in marine sediments: a model study. Global Biogeochem Cycles 1996; 10: 661-73.

[40] Lohse L, Kloosterhuis HT, Raaphorst WV, Helder W. Denitrification rates as measured by the isotope pairing method and by the acetylene inhibition technique in continental shelf sediments of the North Sea. Mar Ecol Prog Ser 1996; 132: 169-79.

[41] Perry MJ, Bolger J, English DC. In: Hickey B, Landry M, Eds. Primary production in Washington coastal waters. Coastal oceanography of Washington and Oregon. Elsevier, New York, NY 1989; 117-38

[42] Brzezinski MA. The Si:C:N ratio of marine diatoms: interspecific variability and the effect of some environmental variables. J Phycol 1985; 2: 347-57

[43] Walsh JJ, Dieterle DA, Maslowski W, et al. A numerical model of seasonal primary production within the Chukchi/Beaufort Seas. Deep-Sea Res II 2005; 52: 3541-76.

[44] Berelson WM, Anderson R, Dymond J, et al. Biogenic budgets of particle rain, benthic remineralization and sediment accumulation in the Equatorial Pacific. Deep-Sea Res 1997; 44: 2251-82.

[45] Yu E-F, Francois R, Bacon MP, et al. Trapping efficiency of bottom-tethered sediment traps estimated from the intercepted fluxes of ${ }^{230} \mathrm{Th}$ and ${ }^{231} \mathrm{~Pa}$. Deep-Sea Res 2001; 48: 865-89.
[46] Francois R, Honjo S, Krishfield R, Manganini S. Factors controlling the flux of organic carbon to the bathypelagic zone of the ocean. Global Biogeochem Cycles 2002; 16: 3401-20.

[47] Treguer P, Nelson DM, Van Bennekom AJ, DeMaster DJ, Leynaert A, Queguiner B. The silica balance in the world ocean: a reestimate. Science 1995; 268: 375-9.

[48] Primeau F. On the variability of the exponent in the power law depth dependence of POC flux estimated from sediment traps. Deep-Sea Res 2006; 53: 1335-43.

[49] Hill V, Cota G, Stockwell D. Spring and summer phytoplankton communities in the Chukchi and Eastern Beaufort Seas. Deep-Sea Res 2005; 52: 3369-85.

[50] Berelson WM. The flux of particulate organic carbon into the ocean interior: a comparison of four U.S. JGOFS regional studies. Oceanography 2001; 14: 59-67.

[51] Walsh JJ, Dieterle DA, Esaias WE. Satellite detection of phytoplankton export from the mid-Atlantic bight during the 1979 spring bloom. Deep-Sea Res 1987; 34: 675-703.

[52] Walsh JJ, Rowe GT, Iverson RL, McRoy CP. Biological export of shelf carbon is a sink of the global $\mathrm{CO}_{2}$ cycle. Nature $1981 ; 291$ : 196-201.

[53] Wroblewski JS, Hofmann EE. U.S. Interdisciplinary modeling studies of coastal - offshore exchange processes: past and future. Prog Oceanogr 1989; 23: 65-99

[54] Rowe GT, Smith S, Falkowski P, et al. Do continental shelves export organic matter? Nature 1986; 324: 559-61.

[55] Bates NR, Hansell DA, Moran SB, Codispoti LA. Seasonal and spatial distribution of particulate organic matter (POM) in the Chukchi and Beaufort Seas. Deep-Sea Res II 2005; 52: 3324-43.

[56] Bourke RH, Paquette RG. Atlantic water on the Chuykchi shelf. Geophys Res Lett 1976; 3: 629-32.

[57] Mountain DB, Coachman LK, Aagaard K. On the flow through Barrow Canyon. J Phys Ocean 1976; 6: 461-70.

[58] Johnson WR. Current response to wind in the Chukchi Sea: a regional coastal upwelling event. J Geophys Res 1989; 94: 2057-64.

[59] Aagaard K, Roach AT. Arctic Ocean-shelf exchange: Measurements in Barrow Canyon. J Geophys Res 1990; 95: 18163-75.

[60] Hill VJ, Cota GF. Spatial patterns of primary production on the shelf, slope and basin of the Western Arctic in 2002. Deep-Sea Res 2005; 52: 3344-54.

[61] Bates NR, Best MHP, Hansell DA. Spatio-temporal distribution of dissolved inorganic carbon and new community production in the Chukchi and Beaufort Seas. Deep-Sea Res 2005; 52: 3303-23.

[62] Hufford GL. On apparent upwelling in the southern Beaufort Sea. J Geophys Res 1974; 79: 1305-6.

[63] Swift JH, Jones EP, Aagaard K, et al. Waters of the Makarov and Canada Basins. Deep-Sea Res 1996; 44: 1503-30.

[64] Barton ED, Huyer A, Smith RL. Temporal variation observed in the hydrographic regime near Cabo Corveiro in the northwest African upwelling region, February to April 1974. Deep-Sea Res 1977; 24: $7-23$

(C) John P. Christensen et al.; Licensee Bentham Open.

This is an open access article distributed under the terms of the Creative Commons Attribution License (http://creativecommons.org/licenses/by/2.5/), which permits unrestrictive use, distribution, and reproduction in any medium, provided the original work is properly cited. 